\title{
Effects of informal competition on innovation performance: the case of Pacific Alliance
}

\author{
Jorge Heredia ${ }^{1 *}$, Alejandro Flores ${ }^{1}$, Cristian Geldes ${ }^{2} y$ Walter Heredia ${ }^{1}$
}

\begin{abstract}
This study evaluates the impact of informal competition on the innovation performance of formal fi rms in emerging ec onomies. A theoretical model under the strategy tripod framework is proposed. It analyzes the effects of Institutional factors as the quality of governance and market labor rigidities on innovation performance, and the mediating effect of informal competition. It is used the Causal Mediation Analysis with data from 3,268 companies from the World Bank Enterprise Survey from countries of the Pacific Alliance (Chile, Colombia, Mexico, and Peru). The results state that informal competition has a negative effect on the innovation performance of formal companies. Based on these findings, It is suggested some promising avenues for future research and managerial implications.
\end{abstract}

Keywords: Informal competition; innovation performance; emerging economies; Pacific Alliance.

Submitted: August $30^{\text {th }} 2017$ / Approved: November $5^{\text {th }} 2017$

\section{Introduction}

The informal economy is defined as economic activities related to the production and trade of goods and services that are not registered or are conducted by unregistered entities; such activities operate outside of government regulation and tax systems (Webb et al., 2013). According to Schneider (2002), more than 50\% of the gross domestic product of emerging economies is connected to the informal economy. Becoming an important area of study. Indeed, researchers who study informality in Latin American countries and Eastern Europe and Central Asia agree that companies must now address two types of competitors, both formal and informal (McCann \& Bahl, 2016, Mendi \& Costamagna, 2017). Because they avoid the costs associated with regulatory compliance and tax payments, informal competitors enjoy relative cost advantages that allow them to undervalue their products. As a result, they may remain in the market despite their low productivity (Farrell, 2004; Perry et al., 2007).

However, the influence of the informal economy on strategic management within the formal economy remains unexplored (Webb, Ireland, \& Ketchen, 2014). Different studies consider informal competition as a relevant factor in the competitive dynamics of industries in emerging economies and on formal enterprises. In this sense, Iriyama, Kishore \& Talukdar (2016) found in IT industry in India, that informal competition increases the non-market competitive corruption activities of formal enterprises, which aim to reduce the benefits that informal enterprises derive from their lower costs in terms of money and time. Additionally, Mendi \& Costamagna (2017) found that informal competition has a negative effect on innovation types (process and product). These relationships were tested with data from the World Bank taken from a sample of African and Latin American countries. These results are relevant because the study of informal activity can yield important insights in areas such as the boundaries of the firm, diversification, dynamic capabilities, the resource-based view, property rights, disruptive technology, and innovation (McGahan, 2012).
Given the importance of informal competition, it is essential to explore the effects of this phenomenon on the innovation capacity of Latin American companies and analyze how informal competition's interaction with institutional factors affects innovation, and which strategies companies can use to mitigate the effects of informal competition on innovation performance (Grazzi \& Pitrobelli, 2016; Webb et al., 2014). For both the theory and the practice of strategic processes, it is important to analyze how Latin America's particular conditions interrelate and influence the enterprises' innovation performance (Mendi \& Costamagna, 2017). In the same vein, other arguments highlighting the need to analyze the relationship between informal competition and innovative performance are that no theory has attempted to explain the effect of quality of governance on the informal competition among, and the innovation performance of companies in emerging economies. In particular, the effect of quality of governance on strategic processes such as innovation has been ignored (Becheikh, Landry \& Amara, 2006). Moreover, the factors behind innovation performance in emerging economies are underexplored, as most studies have been conducted in developed countries, where conditions are different from those of emerging economies (Grazzi \& Pitrobelli, 2016).

The purpose of this study is to analyze the effects of informal competition on innovation performance, taking the case of the countries belonging to the Pacific Alliance (Chile, Colombia, Mexico, and Peru) as representative of Latin American and emerging economies. These relationships are evaluated with Casual Mediation Analysis (Hicks \& Tingley, 2011), and previous evaluations of the proposed theoretical model with Structural Equation Modelling (SEM) (Hair et al., 2010; Hoyle, 2012). The data are from 3,268 manufacturing firms from the "World Bank Enterprise Survey" (2010). To build the theoretical model between informal competition and innovation performance, we draw from the strategy tripod which argues that the management of innovation might be based not only on the firm's ability to enhance

(1) Business School, Universidad del Pacífico. Lima, Perú.

(2) Assistant Professor, Faculty of Economy and Business, Universidad Alberto Hurtado, Santiago, Chile Corresponding author: ja.herediap@up.edu.pe 
its internal resources and capabilities, as in the resource-based view, but also on industry (informal competition) and institutional effect (Peng et al., 2008). Thus, the impact of informal competition on key issues such as innovation is an unexplored field, the study of which may lead to promising new conceptual frameworks, thus furthering our understanding of how Latin America's specific environment influences the sustainability of its companies' competitive advantages. Against this backdrop, we propose the following research questions: a) Does informal competition affect the innovativeness of companies in the Pacific Alliance? If so, how does it affect them? And b) How do the quality of governance, market labor rigidities and informal competition interact? In sum, this study presents a theoretical model for empirical validation that explains how the quality of governance, market labor rigidities and informal competition simultaneously, and directly or indirectly, influence the innovation performance of companies in emerging economies, generating theoretical and managerial implications.

In the next sections, we discuss the literature including the strategy tripod approach as the theoretical approach, the effects of quality of governance and market labor rigidities on innovation performance through informal competition and the influence of informal competition on innovation performance. Next, the method is explained and data. Then, the results are discussed in the context of emerging economies. We conclude with our findings, implications for managers and policymakers.

\section{Conceptual background, theoretical model and hypothesis}

In emerging economies, the strategy tripod proposed by Peng et al., (2008) refers to institutional, industry and firm factors (resources and strategic capabilities) that are complementary and relevant to explaining strategic behavior and business performance. In this study, the strategy tripod approach is applied to the study of factors affecting the innovation performance of firms in emerging economies. Specifically, the strategy tripod approach gives the theoretical framework to identify and analyze external factors (institutional) affecting innovation performance of the firm. In this case, it is selected two categories following the Borrmann, Busse \& Neuhaus (2006) division of institutional factors: the quality of governance and labor rigidities. In the following sections, it is argued and stated the effect of the selected external factors in innovation performance and their hypothesis. These assumptions are shown in the theoretical proposed model (Figure 1). Basically, the model explains how external factors affect the innovation performance and the mediating role of informal competition.

Figure 1. Theoretical model.

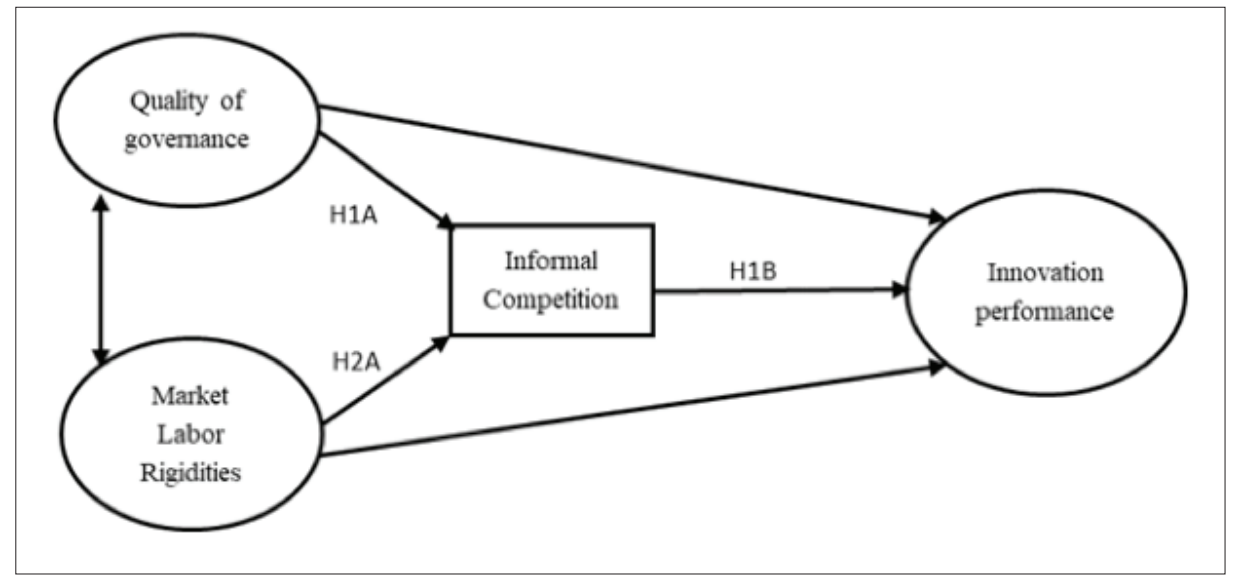

\subsection{The influence of informal competition on innovation performance}

Most studies of innovation performance have been conducted in developed economies, where the external and internal factors that influence innovation performance have been previously identified (Becheikh et al., 2006; Geldes \& Felzensztein, 2013; Geldes et al., 2017). In particular, Latin America and many developing countries are characterized by a unique environment that experiences sudden changes in economic volatility and significant increases in informal competition (unregistered firms) (Vassolo et al., 2011)but it also faces serious challenges that severely underscore these opportunities. We apply a simple framework of analysis to describe the Latin American business environment and detect research opportunities. For that, we focus on four aspects of the region: (1. However, no study has inves- tigated the impact of informal competition (unregistered firms) on innovative performance in Latin America (Webb et al., 2014). Our aim in this article is to better understand the conditions under which informal competition (unregistered firms) affect innovation performance through the indirect effect of quality of governance. Current measures of innovation performance can be roughly divided into two categories: input measures and output measures. Input measures evaluate how innovation activities have been arranged and how resources are allocated to them. Output measures evaluate the effects of successful innovations (Becheikh et al., 2006). We define the innovative performance construct according to Becheikh et al., (2006) and consider the following as inputs: research and development, and purchases of licenses to use intellectual property. As outputs, we consider sales of new/significantly improved products. 


\subsection{The indirect effect of the quality of governance on innovation} performance mediated by informal competition

In relation to the quality of governance, formal innovative industries find their performance negatively impacted by regulation, i.e., taxes or bribery, when interacting with the government (Grazzi \& Pitrobe1li, 2016). Moreover, excessive regulations are the main reason for the existence of a large informal sector, which chooses to operate informally to avoid the costs, time demands, and procedures imposed by the formal regulatory environment (De Soto, 2000). In addition, studies have shown that when government regulations were effectively enforced, the percentage of firms affected by informal competition increased (Tokman, 1978).

To measure the quality of governance, Kaufmann, Kraay \& Mastruzzi (2009) propose six dimensions: political instability, voice and accountability, corruption control, the rule of law, government effectiveness and regulatory quality. Low institutional quality, represented by increases in corruption and insecurity and by excessive regulation informal competition in emerging economies (Tokman, 2001). The interconnection between institutions and the informal sector may be partially explained by the country's institutional setting, and, conversely, the presence of an informal sector may affect institutional efficiency (Mendi \& Costamagna, 2017). This informal competition negatively influences formal companies' ability to innovate in sluggish emerging economies, which have low barriers to entry and plentiful opportunities for imitation due to the lack of protection of intellectual property, as well as the lower competitive advantage (Allred \& Park, 2007; Godfrey, 2011). Additionally, if the Intellectual Property Right (IPR) are weak and ineffective (Allred \& Park, 2007) discourages manufacturing firms from filing for new patents related to their innovations (Allred \& Park, 2007). Given the weakness of Latin America's IPR system, this factor is especially relevant in our Latin American context (Barros, 2015; Grazzi \& Pietrobelli, 2016). With these backgrounds, it is proposed the following hypothesis:

H1: The quality of governance indirectly influences companies' abilities to innovate when there is informal competition in emerging economies.

H1A: The quality of governance is positively related to informal competition in emerging economies.

H1B: The informal competition is negatively related to innovation performance in emerging economies.

\subsection{The indirect effect of market labor rigidities on innovation performance mediated by informal competition}

The second category of institutional factors that are considered in this study is that of labor rigidities (regulations). Labor rigidities, according to Borrmann et al., (2006), including paying taxes, obtaining credits and managing licenses. In addition, Thai \& Turkina, (2014) enrich the category of labor rigidities by including supply factors (resources and abilities) as a category that contains both labor regulations and human development. Excessive use of the regulations (e.g., labor market rigidities) and procedures for business development provided by institutions influence the increase in the number of informal businesses (Webb et al., 2014) in emerging economies A poor support system, represented by a high level of labor rigidity and lack of qualified personnel, increases informal competition in companies in emerging economies (Ketchen, Ireland \& Webb, 2014). Furthermore, formal and informal firms compete for the same customers and resources (McGahan, 2012). The resulting informal competition reduces firms' innovation performance by means of imitation.

H2: Market labor rigidities indirectly influence the innovation performance of formal enterprises through informal competition.

H2A: Market labor rigidities increases informal competition in emerging economies.

\section{Data and Method}

In the following section, it is described the data, the case of study and the method.

\subsection{Data and case of study}

To test the hypotheses, it is employed the 2010 "World Bank Enterprise Survey". The surveys provide information on the companies' characteristics, strategies, and economic performance, as well as their perceptions of the institutional, policy, and economic environment and the degree of competition in which they operate. The Enterprise Survey data have been featured in a number of previously published studies in the field of informal competition (Iriyama et al., 2016; Mccann \& Bahl, 2016; Mendi \& Costamagna, 2017).

The case of study are the countries of the Pacific Alliance a trade initiative, namely Chile, Colombia, Mexico, and Peru. This selection is a response to a diverse range of issues. The group of countries hosts $38 \%$ of the population of Latin America and 34\% of its GDP. Moreover, the group already accounts for half of intraregional trade, $50 \%$ of regional trade with Asia and $42 \%$ of foreign direct investment in Latin America. Chile and México have shown strong economic growth over the past ten years, with growth rates between $6 \%$ and $8 \%$ (Illescas \& Jaramillo, 2011), high export volumes and the implementation of trade liberalization policies that foster international trade. Although Peru has not been considered in the previous studies we examined, it was included in our sample because, in recent years, Peru has also experienced a rapid increase in its exports of goods and services as a percentage of GDP. During the period 2005-2010, Peru had a median growth rate of 5.5\% of its GDP (Illescas \& Jaramillo, 2011; PeñaVinces et al., 2017). According to with World Bank Enterprise Survey (2010), the economy percent of firms competing against unregistered or informal firms for each country are Chile (55.8), Colombia (70.9), Mexico (70.3), and Peru $(68,6)$.

The data, corrected for outliers and missing values, included interviews at 3,268 manufacturing firms in the year 2010. The Enterprise Surveys collect data from key manufacturing and service sectors and employ a standardized format and uniform sampling methodology to 
minimize measurement error and make the data comparable across countries. We focus on manufacturing industries because they have the imperative to continually invest in innovation and are more consistent in their reporting procedures for innovation investment compared with other industrial categories such as services or non-profits (Allred \& Park, 2007). Moreover, innovation is relatively more important in manufacturing and services industries, where value added originates and knowledge and skills are more valued (Crespi \& Zuniga, 2012) Chile, Colombia, Costa Rica, Panama, and Uruguay. Additionally, the determinants of innovations and the effects of the different types of innovation are specific to each economic sector (Geldes et al., 2017).

\subsection{Method}

The method follows the guidelines of Structural Equation Modelling (SEM). The latent variables and the theoretical model are built with Exploratory Factor Analysis (EFA) and Confirmatory Factor Analysis (CFA), with SEM the hypotheses are tested (Hoyle, 2012). Table 1 provides a detailed summary of indicators for each latent variable: (i) Labor Support, (ii) Quality of governance and (iii) Innovation performance. The remaining variable, the mediator Informal Competition, is considered observable (continuous).

Table 1: Summary of variables and constructs.

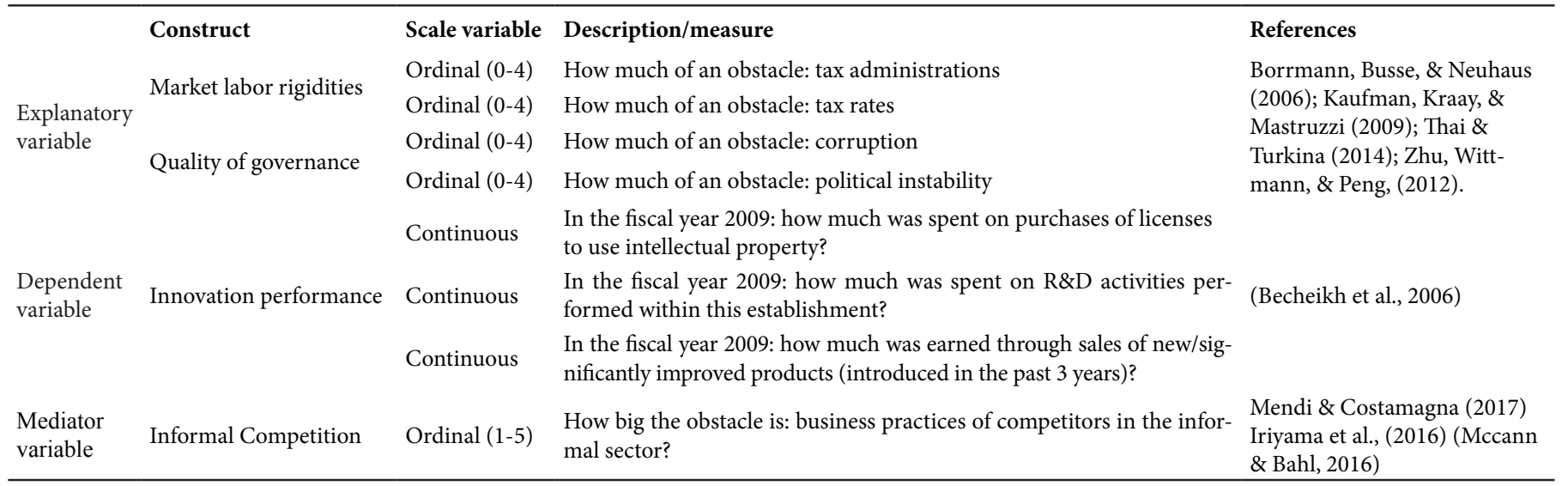

Additionally, in Table 2 are the tests of latent variables for i) reliability (Cronbach's alpha $>0.7$; Construct reliability - CR $>0.7$ ), ii) Convergent validity (Standardized factor loading - FL $>0.5$; Average variance extracted - AVE $>0.5$ ) and iii) Discriminant validity (AVE $>$ MSV - Maximum shared variance squared; AVE $>$ ASV Average variance shared square) (Hair et al., 2010).

Table 2: Test of latent variables.

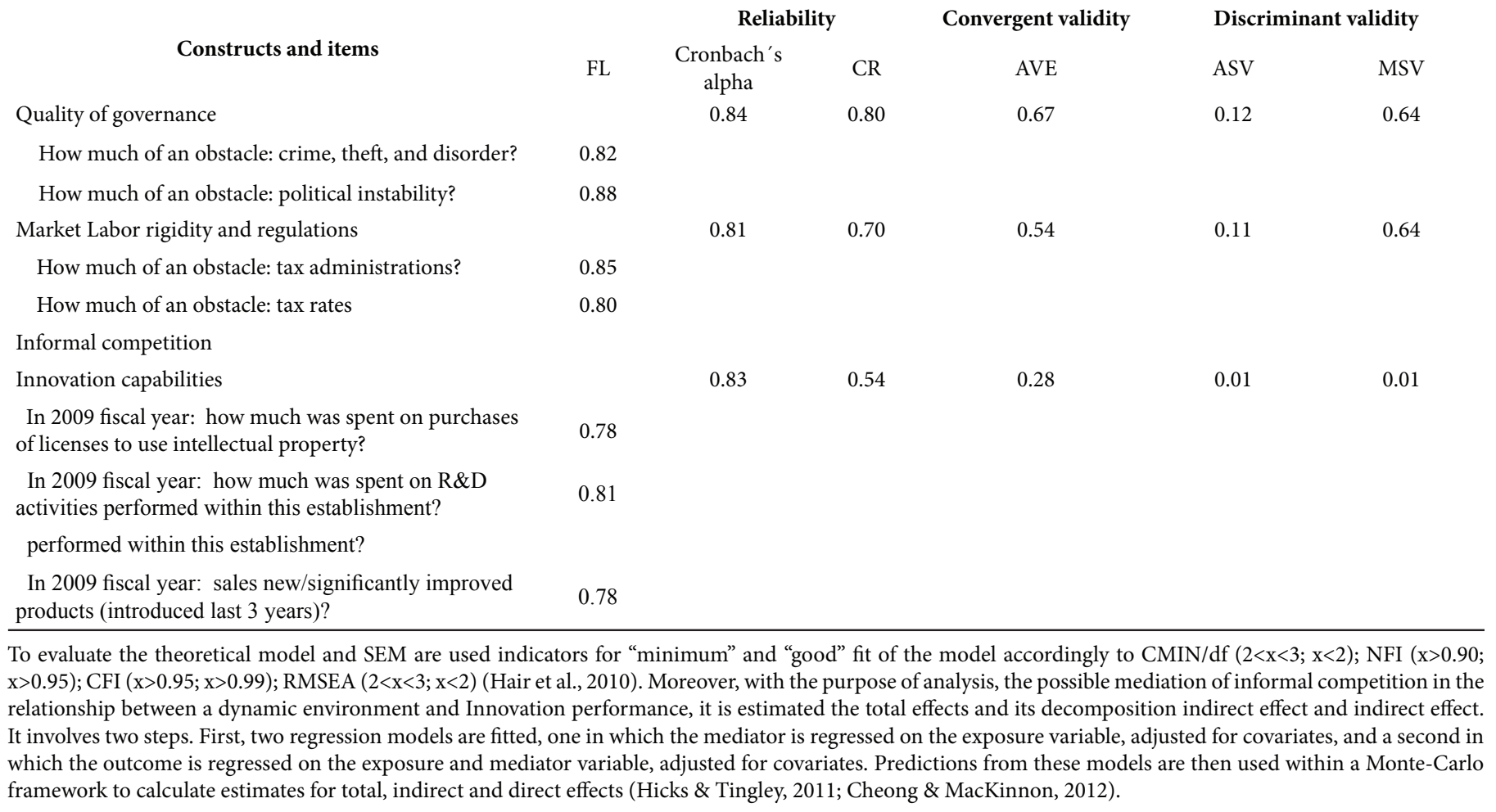




\section{Results and Discussion}

The Figure 2 shows that all the correlation between the variables in SEM model is statistically significative, with the exception on the relation between market labor rigidities and innovative performance. Moreover, the SEM has a good level of fit and the latent variables accomplish with all requirements, with the exception of market labor rigidities with low levels of convergent validity. This last point can be explained due to nature of secondary data. Additionally, in relation to the hypotheses, it is stated the $\mathrm{H} 1 \mathrm{~A}$ is no rejected meaning that the quality of governance is positively related to informal competition in emerging economies with a correlation of 0.12 . In the second term, the $\mathrm{H} 1 \mathrm{~B}$ is no rejected too. It is mean that the informal competition is negatively related to innovation performance in emerging economies (-0.24). In the case of $\mathrm{H} 2 \mathrm{~A}$, it is no rejected, then market labor rigidities are related to informal competition (0.24). Moreover, there is a significative and positive relationship between the quality of governance and the market labor rigidities $(0.63)$.

Figure 2. SEM.

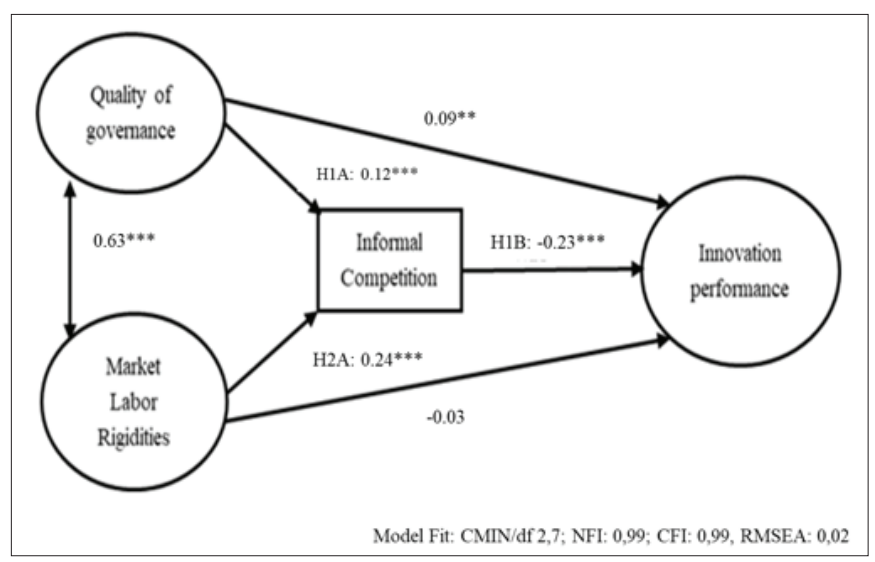

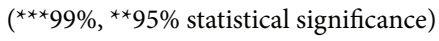

In relation to $\mathrm{H} 1$ "The quality of governance indirectly influences companies' abilities to innovate when there is informal competition in emerging economies" and H2 "Market labor rigidities indirectly influence the innovation performance of formal enterprises through informal competition", both hypotheses are not rejected, demonstrating the mediation role of informal competition. Table 3 shows the indirect effect in both cases and they represent $45 \%$ and $67 \%$ of effect mediated. These results are relevant for the competitive strategy of firms in emerging economies. The governments of emerging countries, such as those of the Pacific Alliance, have initiated national programs to support innovation and increase spending on innovation, with the goal of helping companies improve their competitive advantage in the global environment (Ketelhöhn \& Ogliastri, 2013). However, the innovative performance of Latin American countries is still low (Olavarrieta \& Villena, 2014). Our empirical analyses first demonstrated that informal competition has a negative effect on the innovation performance of formal firms. Formal firms change their behavior due to informal competition (unregistered firms), which capture returns from the formal firms' innovative efforts by copying. Therefore, formal firms invest less in innovation. Our findings reinforce a quantitative study by Mendi \& Costamagna, (2017) which used data from the World Bank of African and Latin American countries and found that informal competition has a negative effect on innovation types (process and product). In addition, similar evidence is found in the Chinese market, in which informal competition affects firm investment in R\&D (Su, Xie, \& Peng, 2010).

Table 3: Mediation analysis. Total Effect and Indirect Effect.

\begin{tabular}{lcccc}
\hline Variables & Total effect & $\begin{array}{c}\text { Direct } \\
\text { effect }\end{array}$ & $\begin{array}{c}\text { Indirect } \\
\text { effect }\end{array}$ & $\begin{array}{c}\% \text { effect } \\
\text { mediated }\end{array}$ \\
$\begin{array}{l}\text { Quality of } \\
\text { governance }\end{array}$ & 0,07 & 0,10 & $-0,03$ & $45 \%$ \\
$\begin{array}{l}\text { Market labor } \\
\text { rigidities }\end{array}$ & $-0,09$ & $-0,03$ & $-0,06$ & $67 \%$ \\
\hline
\end{tabular}

\section{Conclusions, implications and limitations}

The governments of emerging countries intend to support innovation with the goal of helping firms to improve their competitive advantage in the global environment. However, our empirical analyses demonstrated that informal competition has a negative effect on the innovation performance of formal firms. These firms change their behavior due to informal competition (unregistered firms), which capture returns from the formal firms' innovative efforts by copying. Therefore, formal firms invest less in innovation and governments' goals are not achieved. It is clear that firms do not progress on their foundations of competitive behavior. However, the negative effect of informal competition is not uniform across companies in different industries, for example, high barriers to entry and high fixed costs act as natural barriers to informal competition. More research on competitive actions to reduce the impact of informal competition is necessary to identify the right approach to help formal firms to thrive in unfriendly competitive landscapes.

\subsection{Implications}

These results have theoretical and practical implications. From a theoretical point of view, informal competition is a new variable that should be included in the study of innovative performance and strategic behavior in emerging economies, along with quality of governance and labor market rigidities.

From a practical point of view, managers in charge should not overlook the influence of informal competition. Our work confirms that informal competition negatively affects the innovative performance of formal firms. Such competition requires companies to implement activities that allow the configuration of their innovation capabilities. These activities may include investing in technology to differentiate themselves and to maintain competitive advantage in environments of informal competition.

\section{2.- Limitations}

There are some limitations of our study. First, the secondary sources of information we have used shed light on only one construct of innovation performance. Therefore, future research should consider the development and validation of new quantitative scales to assess model robustness (Becheikh et al., 2006). 
Second, this study is context-specific, as it focuses solely on Pacific Alliance (i.e., Chile, Colombia, Mexico, and Peru) firms. Owing to the great differences between the Pacific Alliance and other emerging economies, the generalizability of our conclusions may be limited. Therefore, applicability to other emerging economies must be validated. However, this limitation leads to a series of new research opportunities to investigate our model in other countries and contexts, such as China or other Latin American countries.

Finally, the cross-sectional nature of research into a dynamic concept enables analysis of the organizations' situations at only one specific point in time rather than their overall conduct over a period of time. Future research should consider performing evaluations using panel data analysis.

\section{References}

Allred, B. B., \& Park, W. G. (2007). The influence of patent protection on firm innovation investment in manufacturing industries. Journal of International Management, 13(2), 91-109. http://doi.org/10.1016/j. intman.2007.02.001

Becheikh, N., Landry, R., \& Amara, N. (2006). Lessons from innovation empirical studies in the manufacturing sector: A systematic review of the literature from 1993-2003. Technovation, 26(5-6), 644664. http://doi.org/10.1016/j.technovation.2005.06.016

Borrmann, A., Busse, M., \& Neuhaus, S. (2006). Institutional Quality and the Gains From Trade Axel. Kyklos, 59(3), 345-368. http://dx.doi.org/10.1111/j.1467-6435.2006.00336.x

Byrne, B. M. (2013). Structural equation modeling with AMOS: Basic concepts, applications, and programming. Routledge.

Crespi, G., \& Zuniga, P. (2012). Innovation and Productivity: Evidence from Six Latin American Countries. World Development, 40(2), 273-290. http://doi.org/10.1016/j.worlddev.2011.07.010

Cheon, J. \& MacKinnon (2012). Mediation/indirect effects in structural equation modelling. In: Handbook of Structural Equation Modelling. Rick Hoyle Ed. The guilford Press, New York and London, 417-435 p.

De Soto, H. (2000). The mystery of capital: Why capitalism triumphs in the West and fails everywhere else. Basic books.

Geldes, C. \& Felzensztein, C. (2013). Marketing innovations in the agribusiness sector. Academia Revista Latinoamericana de Administración,, Vol. 26, Issu 1, 108-138. https://doi.org/10.1108/ARLA-052013-0042

Geldes, C., Felzensztein, C. \& Palacios-Fenech, J. (2017). Technological and non-tecnological innovations, performance and propensity to innovate across industries: The case of an emerging economy. Industrial Marketing Management, Vol 61, 55-66. https://doi.org/10.1016/j. indmarman.2016.10.010
Godfrey, P. C. (2011). Toward a Theory of the Informal Economy. The Academy of Management Annals, 5(1), 231-277. http://doi.org/10.10 80/19416520.2011.585818

Grazzi, M., \& Pitrobelli, C. (2016). Firm Innovation and Productivity in Latin America and the Caribbean. (Inter-American Development Bank, Ed.). Washington, DC, USA: Springer Nature.

Hair, J. F., Anderson, R. E., Tatham, R. L., \& Black, W. C. (2010). Multivariate Data Analysis (7th Edition). Pearson Prentice Hall.

Hicks, R., \& Tingley, D. (2011). Causal mediation analysis. Stata Journal, 11(4), 605-619. http://doi.org/The Stata Journal

Hoyle, R. (2012). Introduction and Overview. In: Handbook of Structural Equation Modelling. Rick Hoyle Ed. The guilford Press, New York and London, 3-6 p.

Illescas, J. H., \& Jaramillo, C. F. (2011). Export growth and diversification: the case of Peru (World Bank policy research working paper No. 5868). Washington, DC.

Iriyama, A., Kishore, R., \& Talukdar, D. (2016). Playing dirty or building capability? Corruption and hr training as competitive actions to threats from informal and foreign firm rivals. Strategic Management Journal Strat., 51(2), 315-334. http://doi. org/10.1002/smj

Kaufmann, D., Kraay, A., \& Mastruzzi, M. (2009). Governance Matters VIII: Aggregate and Individual Governance Indicators 19962008 (World Bank policy research working paper). Washington, DC. Retrieved from https://openknowledge.worldbank.org/handle/10986/4170

Ketchen, Ireland, R., \& Webb, J. (2014). Toward a Research Agenda for the Informal Economy: A Survey of the Strategic Entrepreneurship Journal's Editorial Board. Strategic Entrepreneurship Journal, 8(1), 95-100. http://doi.org/10.1002/sej.1175

Ketelhöhn, N., \& Ogliastri, E. (2013). Introduction: innovation in Latin America. Academia Revista Latinoamericana de Administración, 26(1), 1-21. http://doi.org/10.1108/ARLA-05-2013-0037

Mccann, B. T., \& Bahl, M. (2016). The Influence of Competition from Informal firms on New Product Development. Strategic Management Journal, 51(2), 315-334. http://doi.org/10.1002/smj

McGahan, A. (2012). Challenges of the Informal Economy for the Field of Management. The Academy of Management Perspectives, 26(3), 12-21. http://doi.org/10.5465/amp.2012.0104

Mendi, P., \& Costamagna, R. (2017). Managing innovation under competitive pressure from informal producers. Technological Forecasting and Social Change, 114, 192-202. http://doi.org/10.1016/j.techfore.2016.08.013 
Olavarrieta, S., \& Villena, M. G. (2014). Innovation and business research in Latin America: An overview. Journal of Business Research, 67(4), 489-497. http://doi.org/10.1016/j.jbusres.2013.11.005

Peng, M., Wang, D. \& Jiang, Y. J Int Bus Stud (2008) 39: 920. https:// doi.org/10.1057/palgrave.jibs. 8400377

Peña-Vinces, J. C., Casanova, L., Guillen, J., \& Urbano, D. (2017). International Competitiveness of Small and Medium-Sized Enterprises: Peru, a Latin-American Emerging Market. Emerging Markets Finance and Trade, 53(1), 150-169. http://doi.org/10.1080/154049 6X.2016.1156525

Schneider, F. (2002). Size and measurement of the informal economy in 110 countries around the world (Paper presented at a Workshop of Australian National Tax Centre). Canberra, Australia.

Su, Z., Xie, E., \& Peng, J. (2010). Impacts of environmental uncertainty and firms' capabilities on R\&D investment: Evidence from China. Innovation: Organization and Management, 12(3), 269-282. https://doi.org/10.5172/impp.12.3.269

Thai, M. T. T., \& Turkina, E. (2014). Macro-level determinants of formal entrepreneurship versus informal entrepreneurship. Journal of Business Venturing, 29(4), 490-510. https://doi.org/10.1016/j.jbusvent.2013.07.005
Tokman, V. (1978). Competition between the informal and formal sectors in retailing: The case of Santiago. World Development, 6(910), 1187-1198. http://doi.org/10.1016/0305-750X(78)90072-4.

Tokman, V. (2001). Las relaciones entre los sectores formal e informal. Una exploración sobre su naturaleza. Economía, 24(48), 7-73. Retrieved from http://revistas.pucp.edu.pe/index.php/economia/article/view/847

Vassolo, R. S., De Castro, J. O., \& Gomez-Mejia, L. R. (2011). Managing in Latin America: Common Issues and a Research Agenda. The Academy of Management Perspectives, 25(4), 22-36. http://doi.org/10.5465/amp.2011.0129

Webb, J. W., Bruton, G. D., Tihanyi, L., \& Ireland, R. D. (2013). Research on entrepreneurship in the informal economy: Framing a research agenda. Journal of Business Venturing, 28(5), 598-614. http://doi.org/10.1016/j.jbusvent.2012.05.003

Webb, Ireland, \& Ketchen. (2014). Toward a greater understanding of entrepreneurship and strategy in the informal economy. Strategic Entrepreneurship Journal, 8(1), 1-15. http://doi.org/10.1002/sej.1176

Zhu, Y., Wittmann, X., \& Peng, M. W. (2012). Institution-based barriers to innovation in SMEs in China. Asia Pacific Journal of Management, 29(4), 1131-1142. http://doi.org/10.1007/s10490-011-9263-7 